Лазарєв Геннадій Юрійович аспірант кафедри Публічного управління та адміністрування Інституту підготовки кадрів державної служби зайнятості України, вул. Нововокзальна, 17, м. Київ, 03038, e-mail: analityka@i.ua, https://orcid.org/0000-0001-5196-6786

\title{
НОРМАТИВНО-ПРАВОВЕ ЗАБЕЗПЕЧЕННЯ РОЗВИТКУ ІННОВАЦІЙНОЇ ІНФРАСТРУКТУРИ ОТГ
}

\begin{abstract}
Анотація. У статті висвітлено сутність понять «інноваційна інфраструктура», «нормативно-правове забезпечення інноваційної інфраструктури ОТГ». Розглянуто реалізацію інноваційного процесу територіальної громади. Зазначено, що підгрунтям для забезпечення впровадження інновацій та розвитку інноваційної інфраструктури територіальної громади $\epsilon$ відповідна нормативно-правова та місцева організаційно-розпорядча база, інноваційна культура, а також система знань та інформації, якими «володіє» дана громада. Розроблено структуру нормативно-правового забезпечення розвитку інноваційної інфраструктури ОТГ. Визначено, що державна політика щодо формування та функціонуванню інноваційної інфраструктури ОТГ повинна бути спрямована на те, щоб нормативно-правова база відповідала вимогам цілісності, комплексності та послідовності науково-технологічного, інноваційного розвитку і підприємництва в складі як регіональної так і національної інноваційної систем. Наведено державне, регіональне і місцеве нормативноправове забезпечення розвитку інноваційної інфраструктури ОТГ та його недоліки (немає чітко визначених правових норм 3 охорони комерційної таємниці, ноу-хау; не визначений правовий режим охорони і використання об'єктів інтелектуальної власності, створених у зв'язку з виконанням трудового договору, сформованих за рахунок коштів державного бюджету; відсутні закріплені на законодавчому рівні заходи, спрямовані на попередження правопорушень у сфері забезпечення прав інтелектуальної власності; відсутнє правове регулювання оцінки вартості об'єктів інтелектуальної власності, їх покупки і взяття на бухгалтерський облік; вимагають вдосконалення процедури трансферу технологій та інститут юридичної відповідальності за правопорушення в сфері інтелектуальної власності). Відмічено основні причини, що знижують ефективність нормативно-правового регулювання інноваційної діяльності ОТГ. Визначено шляхи вдосконалення нормативно-правового забезпечення інноваційної інфраструктури ОТГ.

Ключові слова: інновації, інноваційний процес, інноваційна інфраструктура, нормативно-правове забезпечення, об'єднані територіальні громади.
\end{abstract}


Lazariev Hennadii Yuriiovych Graduate student of the Department of Public Administration of the Institute of Personnel Training of the State Employment Service of Ukraine, Novovokzalna St., 17, Kyiv, 03038, e-mail: analityka@i.ua, https://orcid.org/0000-0001-5196-6786

\title{
REGULATORY AND LEGAL SUPPORT OF DEVELOPMENT OF INNOVATIVE INFRASTRUCTURE OF OTG
}

\begin{abstract}
The article highlights the essence of the concepts "innovation infrastructure", "regulatory and legal support of innovation infrastructure OTG". The implementation of the innovation process of the territorial community is considered. It is noted that the basis for ensuring the implementation of innovations and development of innovation infrastructure of the territorial community is the appropriate legal and local organizational and administrative framework, innovation culture, as well as the system of knowledge and information "owned" by the community. The structure of normative and legal support for the development of OTG innovation infrastructure has been developed. It is determined that the state policy on the formation and functioning of OTG innovation infrastructure should be aimed at ensuring that the regulatory framework meets the requirements of integrity, complexity and consistency of scientific and technological, innovative development and entrepreneurship in both regional and national innovation systems. State, regional and local regulatory support for the development of OTG's innovative infrastructure and its shortcomings are given (there are no clearly defined legal norms on protection of trade secrets, know-how; no legal regime for protection and use of intellectual property created in connection with with the implementation of the employment contract, formed at the expense of the state budget, there are no statutory measures to prevent offenses in the field of intellectual property rights, there is no legal regulation of valuation of intellectual property, their purchase and accounting, require improvement of the technology transfer procedure and the institute of legal liability for intellectual property offenses). The main reasons that reduce the effectiveness of regulatory regulation of innovation activities of OTG are noted. Ways to improve the regulatory and legal support of the OTG innovation infrastructure have been identified.
\end{abstract}

Keywords: innovations, innovation process, innovation infrastructure, normative-legal provision, united territorial communities.

Постановка проблеми. Розвиток інноваційної економіки в Україні неможливий без формування інноваційної інфраструктури, завдання якої забезпечувати взаємовигідні відносини суб'єктів науково-інноваційної, освітньої, виробничої та інформаційної сфери, продуктивну взаємодію процесів породження нових знань. В свою чергу, світові процеси інтеграції та глобалізації, які динамічно розвиваються, призводять до ускладнення форм господарської діяльності, підвищення вимог до якості нормативно-правового забезпечення у сфері інновацій. В умовах децентралізації влади особливого 
значення набувають питання впровадження інновацій в управлінську діяльність об'єднаних територіальних громад (ОТГ) та розроблення напрямів формування інноваційної інфраструктури як запоруки їх стійкого розвитку. Так проблематика нормативно-правового забезпечення розвитку інноваційної інфраструктури на рівні територіальних громад - міст, селищ і сіл набуває дедалі більшої актуальності для сучасної України, виходить на порядок денний нової регіональної політики та внутрішньої державної економічної політики.

Аналіз останніх досліджень та публікацій. Проблематику розвитку сільських територіальних громад досліджували такі автори, як М. Баймуратов, І. Безена, В. Вакуленко, Ю. Ганущак, І. Гурняк [1], О. Дацко [1], П. Жук [2], В. Кравців [2], В. Куйбіда, О. Титаренко, І. Чукіна, О. Яремчук [1]. Особливості інноваційного процесу i його правове забезпечення у вітчизняних дослідженнях розглянуті вченими Ю. Анісімовим, Е. Балашовою, Т. Деділовою [3], Д. Котовим [4], О. Панухник [5], Шапошніковою, О. Шершенюком [3]. Питання аналізу інноваційної інфраструктури та ії елементів, виявлення проблемних аспектів функціонування в ОТГ досліджуються в роботах О. Бабиної, В. Гладіліна, О. Жихора [6], Я. Жовнірчика [7], М.Козоріза [6], Д. Кокурін, В. Мельник [7], А. Мокій [8], Н. Науменко [8], Н. Павліха [8], В. Філатова, С. Яшина.

Водночас, незважаючи на цінність проведених наукових досліджень, окремі аспекти формування інноваційної інфраструктури об’єднаних територіальних громад залишаються недослідженими, а саме актуалізація впровадження інновацій на рівні територіальних громад, їх нормативноправова підтримка і стимулювання.

Метою статті є аналіз нормативно-правових засад розвитку інноваційної інфраструктури ОТГ.

Виклад основного матеріалу. В умовах децентралізації та реформування місцевого самоврядування важливе значення має процес об’єднання територіальних громад (ОТГ), який здійснюється відповідно до «Концепції реформування місцевого самоврядування та територіальної організації влади в Україні» [9] та Закону України «Про добровільне об'єднання територіальних громад» [10].

На протязі 2015-2020 р.p. створено 983 ОТГ з населенням понад 11 млн., 3 них: 936 об'єднань, в яких відбулися перші вибори, 47 ОТГ з центром у містах обласного значення. Рейтинговий список відносно формування спроможних громад очолюють: Волинська (54), Житомирська (56), Запорізька (56), Полтавська (53), Тернопільська (54), Хмельницька (52), Черкаська (57) області. Останні позиції рейтингу - Донецька (13), Закарпатська (17), Луганська (18) області [11].

Визначальним стратегічним напрямом, що спонукає функціонування ОТГ України як територій інноваційного розвитку, виступає активізація підприємницької активності та економічне зростання на основі об“єднання економічних, соціальних та екологічних інтересів громади 3 максимально ефективним залученням ресурсного потенціалу та використанням сучасних 
розумних технологій з метою підвищення якості та рівня життя населення.

На нашу думку, до основних перспективних напрямів спеціалізації господарських комплексів ОТГ України можна віднести: промислове виробництво (зокрема, через побудову Індустріальних парків), виробництво альтернативної енергетики, логістика (планування, закупівля, транспортування та зберігання сільськогосподарської та інших видів продукції), розвиток обслуговуючих громаду об‘єктів (рекреація, відпочинок, торгівля, громадське харчування, побутове обслуговування тощо) та активізація інших видів малого та середнього підприємництва, що використовують передові технології.

Впровадження інновацій у життєдіяльність територіальних громад обумовлена потребами цієї громади як у теперішньому часі, так i y стратегічній перспективі. Реалізація інноваційного процесу територіальної громади зображено на рис. 1 .

На сьогодні основними пріоритетами реалізації моделі інноваційного розвитку ОТГ України $є$ першочергове створення мережі «розумних» будівель, впровадження електронних технологій для вирішення інфраструктурних проблем, зокрема у ЖКГ i енергозбереженні, впровадження технологій е-врядування та системи електронного документообігу, застосування сучасних інформаційно-комунікаційних засобів для покращення надання соціальних послуг тощо [5, с. $65]$.

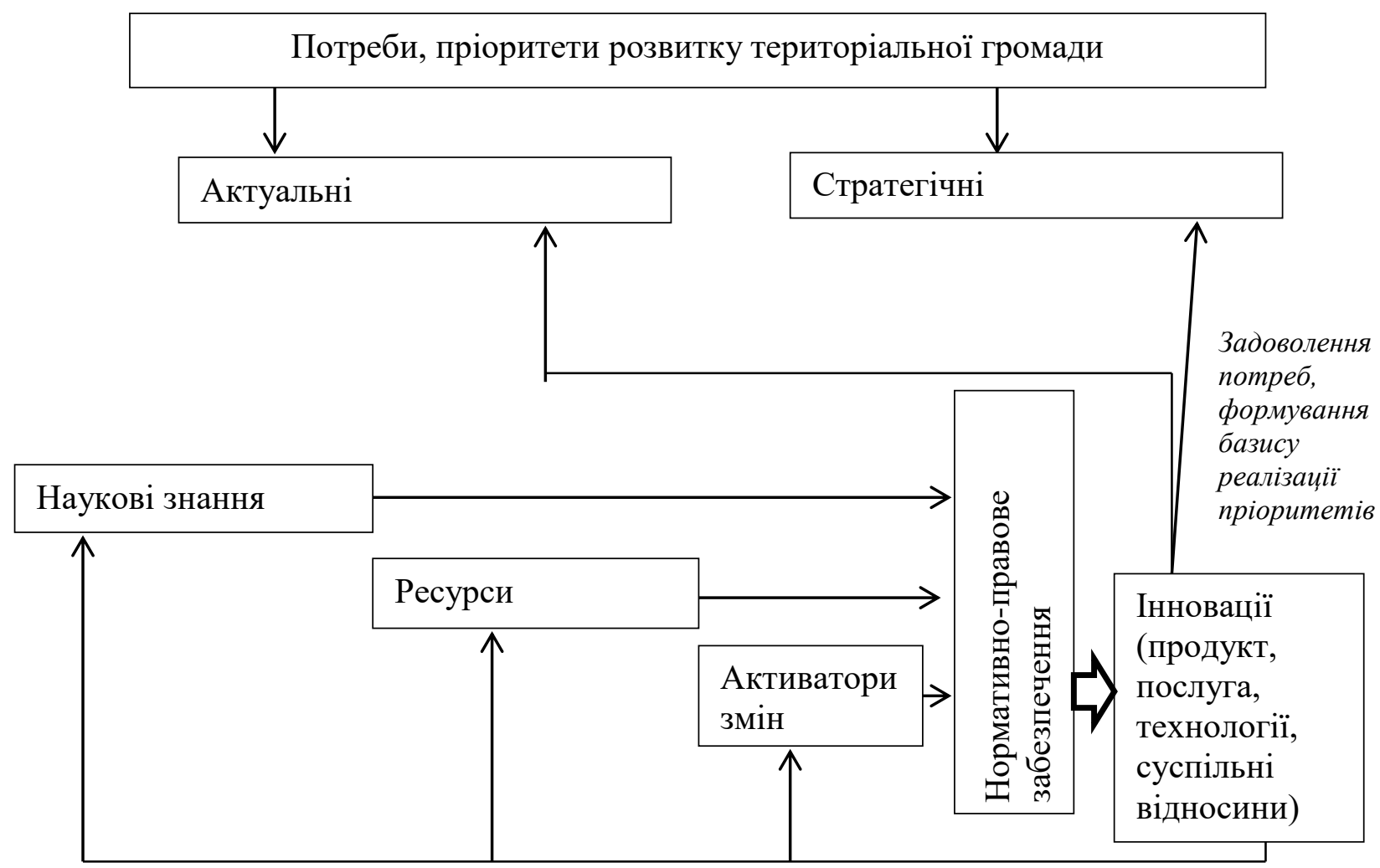

Рис. 1. Реалізація інноваційного процесу територіальної громади Джерело: складено автором на основі [3; 8]

Інноваційний розвиток територіальної громади, як і всієї країни в 
цілому, залежить від наявності тих самих передумов (або компонентів), які складають основу інноваційної системи - інноваційних ресурсів, інноваційної інфраструктури (яка визначається наявністю комплексу інноваційно-орієнтованих організацій та підприємств, їх інтеграційних об’єднань та відповідних інноваційно-ресурсних центрів - за наявністю), інноваційних процесів. Підгрунтям для забезпечення інноваційного розвитку територіальної громади $\epsilon$ відповідна нормативно-правова та місцева організаційно-розпорядча база, інноваційна культура, а також система знань та інформації, якими «володіє» дана громада.

На думку науковців М.Козоріза та О. Жихора, під інноваційною інфраструктурою варто розуміти поєднання діючих споруд, будівель, мереж та систем, що прямо не належать до реалізації інновацій в економічних системах, але таке поєднання $\epsilon$ необхідним для забезпечення цього процесу [6, с. 113].

Аналіз наукової літератури дає підстави стверджувати, що інноваційна інфраструктура, як система, містить окремі складові елементи, які вітчизняна законодавча база виділяє у виробничо-технологічну, фінансово-економічну, нормативно-правову, територіальну та кадрову підсистеми. До них відносяться [6]:

- виробничо-технологічні структури (технопарки, інноваційнотехнологічні центри і бізнес-інкубатори) [6];

- об'єкти інформаційної системи (аналітичні, статистичні центри, інформаційні бази і мережі) [6];

- установи 3 підготовки та перепідготовки кадрів у сфері технологічного менеджменту [6];

- фінансові структури (фонди бюджетні, позабюджетні, венчурні, страхові) [6];

- система експертизи (центри, які здатні зробити експертні висновки для виробників, інвесторів, страхових служб і т.д.) [6];

- об'єкти патентування, ліцензування та консалтингу[6];

- система сертифікації, стандартизації та акредитації [6]

Деякі вітчизняні вчені пропонують розглядати більш розширений варіант складових елементів інфраструктури інноваційної діяльності в залежності від їх функціонального призначення:

1) політико-правове і нормативне регулювання інноваційної діяльності (на всіх рівнях) [5];

2) фінансово-економічне стимулювання, забезпечення i регулювання інноваційної діяльності [5];

3) інформаційно-комунікаційне забезпечення, доступ до інноваційних пропозицій і баз знань [5];

4) консалтингові послуги [8];

5) освіту і кадрове забезпечення професійно підготовленими фахівцями і менеджерами в сфері інновацій [8];

6) виробничо-технічна складова, яка покликана створити умови для полегшеного доступу інноваційно активних підприємств (перш за все малих) 
до ресурсів виробничих потужностей (організація технопарків, інноваційнотехнологічних центрів і комплексів) [5; 8];

7) збут, просування інноваційної продукції на національні та зарубіжні ринки (включаючи маркетинг, рекламну діяльність, захист інтелектуальної власності і т.п.) [5; 8].

Вчений Д. Котов виділяє наступні елементи інноваційної інфраструктури: правова інфраструктура; інформаційна інфраструктура; спеціалізовані інноваційні центри; фінансові інститути (банки, інвестиційні інститути, венчурні фонди, бюджет і ін.) [4]. На наш погляд, не всі фінансові інститути відносяться безпосередньо до інноваційної інфраструктури, а нормативно-правове забезпечення інноваційної діяльності $\epsilon$ необхідною умовою формування і функціонування інноваційної інфраструктури, а не іiі складовим елементом.

Разом $з$ тим, призначення інфраструктурного забезпечення інноваційної діяльності ОТГ проявляється у формуванні механізму взаємодії і встановлення взаємозв'язків суб'єктів інноваційної сфери з метою отримання економічного ефекту, прискорення реалізації інноваційного проекту, зменшення тривалості інноваційного лага, витрат і ступеня ризику в процесі інноваційної діяльності. Інноваційна інфраструктура являє собою допоміжну ланку між підприємством, ринком збуту продукції і ринком пропозицій науково-технічних розробок. Вона містить в собі всю систему обслуговування і підтримки інноваційної діяльності.

Тому варто акцентувати увагу на тому, що територіальна громада відрізняється від інших суб’єктів господарювання тим, що мета іiі життєдіяльності не є хремастичною і не може орієнтуватися винятково на отримання прибутку, а передбачає створення суспільних благ, які формують корисність для всієї територіальної громади. Створення доданої вартості територіальних громад базується на ресурсному потенціалі та його примноженні. На думку вчених Л. Гурняка і О. Дацко, територіальна громада може використовувати для створення продуктових, процесних, технологічних інновацій такі ресурси: природні, людські, технологічні, інфраструктурні, інформаційні, фінансові, соціальні, матеріальні (штучно створені), культурні [1, с. 30]. Для імплементації інновацій потрібні наукові знання, формалізовані у наукові розробки та технологічні процеси, а також активатори змін - креативні люди, які здатні впроваджувати інновації в суспільне життя. Так майже у усіх громадах існують труднощі в освоєнні інновацій. Це пов'язано з відсутністю матеріально-технічної та лабораторнодослідницької бази для їх опанування, а також з відсутністю наукових та інженерних кадрів для ¥ї обслуговування. Здебільшого, науково-технічні інноваційні проекти це розробки провідних наукових установ світу та українських науковців, розуміння яких передбачає відповідний рівень освіти. У свою чергу, це потребує від інноваційно орієнтованих підприємств ОТГ формування такого кадрового складу, який би був спроможним обслуговувати високотехнологічне обладнання. Особливо ці проблеми стосуються сільських об’єднаних територіальних громад, мешканці яких 
обмежені у доступі до високоякісної освіти. В результаті 3 метою капіталізації ресурсного потенціалу територіальних громад необхідним $\epsilon$ відповідне нормативно-правове забезпечення (закони, укази Президента, підзаконні акти у формі постанов Уряду, наказів центральних органів виконавчої влади тощо), формальні чи неформальні правила та механізми, які у певній суспільній групі визначають можливості впровадження інновацій та розвитку інноваційної інфраструктури. Передусім через це нормативноправове забезпечення мають бути ідентифіковані об'єкти, суб'єкти, залучені до інноваційного процесу, а також правила їх використання [7, с. 94].

Підприємство, як ключовий суб’єкт інноваційного процесу, проводить аналіз потреб ринку збуту 3 метою виявлення необхідності випуску інноваційної продукції, яка на даний період часу має підвищений попит. Далі починається етап стратегічного планування та оцінки наявного інноваційного потенціалу підприємства, інноваційного мікро- та макросередовища. Одним 3 ключових чинників, який дозволяє підприємству розраховувати на отримання позитивного ефекту від інноваційної діяльності, $\epsilon$ наявність і врахування можливостей, що надаються інноваційною інфраструктурою ОТГ і конкретного регіону.

Взаємодія між усіма учасниками інноваційного процесу здійснюється відповідно до законів і нормативно-правових актів України. Шляхом їх зміни i коректування визначається вплив держави на формування i розвиток інноваційної інфраструктури ОТГ. Ключову роль в процесі державного регулювання інноваційного підприємництва відіграє напрямок законотворчих органів на створення Інноваційного кодексу України. Саме від його прийняття, на нашу думку, в майбутньому буде залежати якість виконання інноваційною інфраструктурою важливих для активізації інноваційної діяльності функцій, які неможливі без детального визначення $і$ закріплення змісту основних ï понять, видів, складових, етапів формування, методів регулювання і стимулювання відповідно до нормативно-правової бази.

Державна інноваційна політика, законодавство в значній мірі впливають на активізацію інноваційних процесів, стимулювання організації різних форм власності в різних галузях i cферах, які вкладають кошти в розробку інноваційних продуктів, послуг та технологій. Зміни в економічній політиці, конкуренція викликають необхідність постійного пошуку більш ефективних інноваційних технологій, альтернативних ресурсів, розробку інноваційних продуктів. Державна політика щодо формування та функціонуванню інноваційної інфраструктури ОТГ повинна бути спрямована на те, щоб нормативно-правова база відповідала вимогам цілісності, комплексності та послідовності науково-технологічного, інноваційного розвитку i підприємництва в складі як регіональної так і національної інноваційної систем.

Але на сьогодні можливості розвитку інноваційної інфраструктури територіальних громад істотно обмежені через недосконале нормативноправове забезпечення [8, с. 24]. 
3 нашої точки зору, під нормативно-правовим забезпеченням інноваційної інфраструктури ОТГ слід розуміти систему суспільнополітичних інститутів, державних, регіональних і місцевих законодавчих владних структур, органів влади різних рівнів, наділених повноваженнями розробляти і приймати різні нормативно-правові акти, а також сукупність самої нормативно-правової бази та механізмів ії виконання в ОТГ (рис. 2).

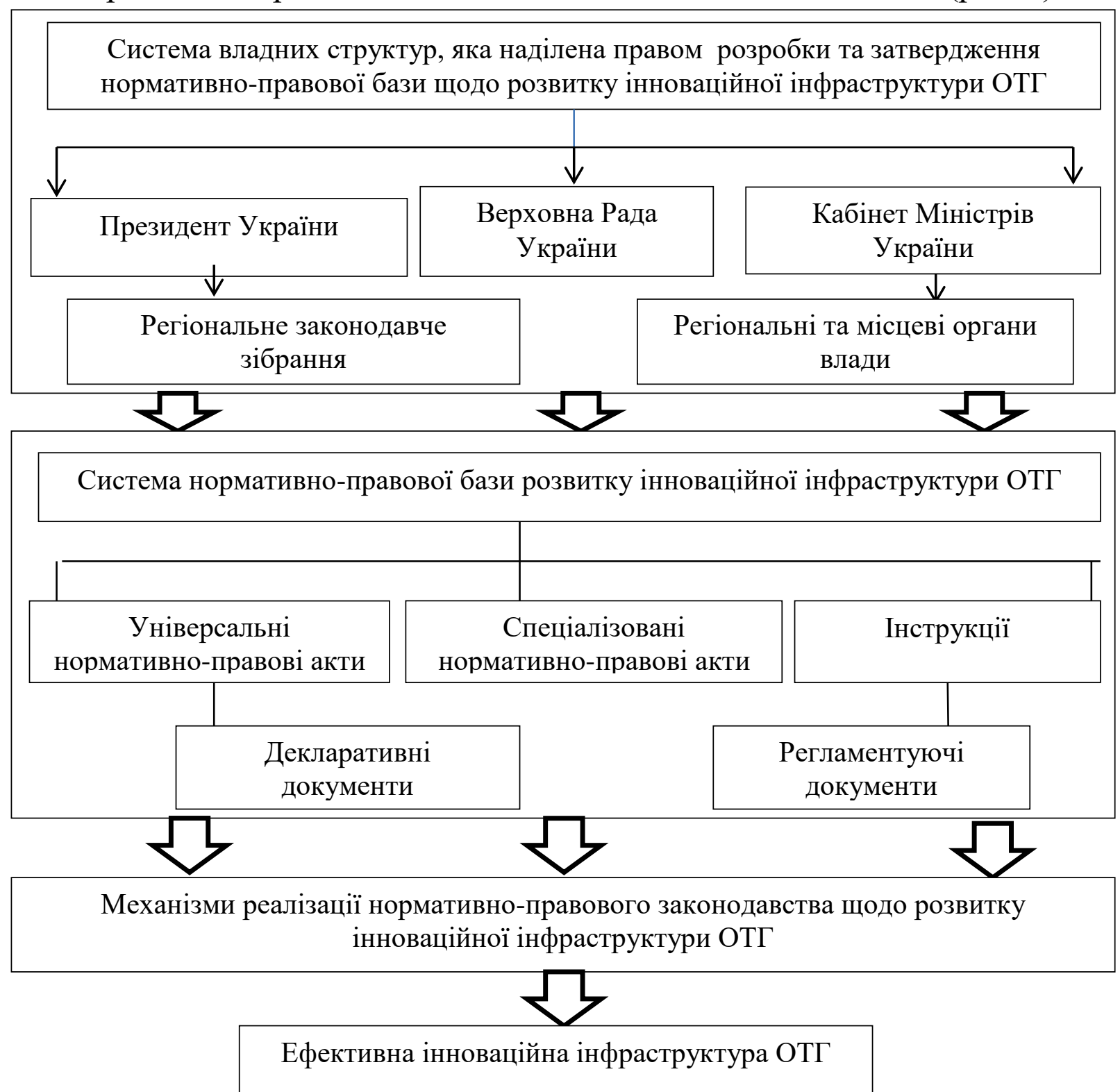

Puc. 2. Структура нормативно-правового забезпечення розвитку інноваційної інфраструктури ОТГ

Джерело: авторська розробка

В Україні ключовим інструментом, який регламентує відносини в інноваційній сфері ОТГ є державне законодавство, що включає норми Конституції України, Господарського кодексу, Закону України «Про інноваційну діяльність» [12], Закону України «Про пріоритетні напрями інноваційної діяльності в Україні» [13], Закону України «Про наукову i науково-технічну діяльність» [14], Закону України «Про спеціальний режим 
інноваційної діяльності технологічних парків» [15], Закону України «Про засади державної регіональної політики» [16], Указу Президента України «Про невідкладні заходи щодо забезпечення економічного зростання, стимулювання розвитку регіонів та запобігання корупції» [17], Розпорядження Кабінет Міністрів України «Про схвалення Стратегії розвитку сфери інноваційної діяльності на період до 2030 року» [18] та інших нормативно-правових актів. Їх завдання - визначення правових, економічних та організаційних засад державного регулювання інноваційної діяльності, встановлення форм стимулювання державою інноваційних процесів, що спрямовані на підтримку розвитку інноваційної інфраструктури ОТГ та України в цілому $[9 ; 10]$ (табл. 1).

Таблиия 1

\section{Нормативно-правове забезпечення розвитку інноваційної} інфраструктури ОТГ

\begin{tabular}{|c|c|}
\hline Назва закону & Зміст \\
\hline $\begin{array}{l}\text { «Про інноваційну } \\
\text { діяльність» }\end{array}$ & $\begin{array}{l}\text { Встановлю форми стимулювання державою } \\
\text { iнноваційних процесів. Спрямований на підтримку } \\
\text { розвитку економіки регіонів та країни в цілому } \\
\text { інноваційним шляхом }\end{array}$ \\
\hline $\begin{array}{lr}\text { «Про пріоритетні } \\
\text { напрями } \\
\text { діяльності в Украційні»ої }\end{array}$ & $\begin{array}{l}\text { Спрямований на забезпечення інноваційної моделі } \\
\text { розвитку економіки шляхом концентрації ресурсів } \\
\text { держави на пріоритетних напрямках науково- } \\
\text { технічного оновлення виробництва, підвищення } \\
\text { конкурентоздатності вітчизняної продукції на } \\
\text { внутрішньому та зовнішньому ринках }\end{array}$ \\
\hline $\begin{array}{l}\text { «Про спеціальний } \\
\text { режим інноваційної } \\
\text { діяльності } \\
\text { технологічних парків» }\end{array}$ & $\begin{array}{l}\text { Визначає правові та економічні основи } \\
\text { впровадження i функціонування спеціального } \\
\text { режиму інноваційної діяльності технологічних } \\
\text { парків }\end{array}$ \\
\hline $\begin{array}{l}\text { «Про наукову } \\
\text { науково-технічну } \\
\text { діяльність» }\end{array}$ & $\begin{array}{l}\text { Визначає правові, організаційні та фінансові } \\
\text { засади функціонування і розвитку у сфері наукової } \\
\text { i науково-технічної діяльності, створює умови для } \\
\text { провадження наукової і науково-технічної } \\
\text { діяльності, задоволення потреб суспільства і } \\
\text { держави у технологічному розвитку шляхом } \\
\text { взаємодії освіти, науки, бізнесу та влади. }\end{array}$ \\
\hline
\end{tabular}

Джерело: складено автором на основі $[12 ; 13 ; 14 ; 15]$

Аналіз вищезазначених законодавчих актів дозволив виявити їх основні недоліки:

- немає чітко визначених правових норм 3 охорони комерційної таємниці, ноу-хау;

- не визначений правовий режим охорони i використання об'єктів 
інтелектуальної власності, створених у зв'язку 3 виконанням трудового договору, сформованих за рахунок коштів державного бюджету;

- відсутні закріплені на законодавчому рівні заходи, спрямовані на попередження правопорушень у сфері забезпечення прав інтелектуальної власності;

- відсутнє правове регулювання оцінки вартості об'єктів інтелектуальної власності, їх покупки і взяття на бухгалтерський облік;

- вимагають вдосконалення процедури трансферу технологій та інститут юридичної відповідальності за правопорушення в сфері інтелектуальної власності.

Важливим напрямком нормативно-правового регулювання в інноваційній сфері ОТГ є регіональне законодавство.

Реалізація регіонального інноваційного законодавства в практиці органів влади суб'єктів країни супроводжується наступними проблемними питаннями:

- наявність протиріч і недостатній рівень гармонізації між державними та регіональними законами, що регулюють розвиток інноваційної інфраструктури;

- обмеженість регіональних бюджетних ресурсів при фінансуванні інновацій, обмеженість регіональних податкових пільг положеннями Податкового кодексу України;

- присутність бар'єрів у вигляді обов'язкових умов при поданні заявок на отримання грантів i позик для виконання НДДКР в регіональному законодавстві і т. д.

Як показує практика застосування описаного державного і регіонального нормативно-правового забезпечення, дане законодавство є відірваним від реалій науки, промисловості, облікових політик та інноваційних програм. Істотним недоліком системи державного регулювання розвитку інноваційної інфраструктури є те, що вона, на відміну від законодавства більшості країн світу, не тільки не сприяє розширенню джерел фінансування інноваційного розвитку, але i протидіє залученню позабюджетних коштів та робить неможливим формування спеціальних, в тому числі відомчих, фондів фінансування інновацій. В даному випадку не менш важливим питанням $\epsilon$ розробка локальних актів на рівні науково-виробничих, промислових підприємств, конструкторських бюро та інших учасників інноваційного процесу.

До базових місцевих документів можемо віднести наступні: статути територіальних громад; документи про приєднання до Ольборзької хартії; концепцію сталого розвитку територіальної громади включно з індикаторами сталого розвитку; концепцію сталого розвитку територіальної громади, або стратегічний план розвитку; місцевий план дій [7, с. 95].

Відмітимо, що важливим нормативно-правовим документом $є$ статут територіальної громади. Більшість сільських територіальних громад не мають розроблених і затверджених статутів, винятково якими визначається порядок реалізації права на безпосередню участь членів територіальних 
громад місцеве самоврядування через місцеві ініціативи, громадські слухання. За відсутності затверджених статутів, члени територіальних громад позбавлені права на безпосередню участь в місцевому самоврядуванні у формі місцевих ініціатив і громадських слухань, а відповідно, i у механізмах ініціювання інноваційних комунальних проектів [2, с. 10].

Варто зазначити, що законодавча платформа забезпечення розвитку інноваційної інфраструктури ОТГ вимагає доопрацювання. Основні причини, що знижують ефективність нормативно-правового регулювання інноваційної діяльності в ОТГ, включають в себе:

1. Творчий характер інноваційної діяльності, наявність високих ризиків і невизначеностей при укладанні договорів на виробництво продукції, виконання робіт, надання послуг інноваційного характеру.

2. Недостатній рівень взаємозв'язку між такими нормативно-правовими актами, що спрямовані на забезпечення інноваційної діяльності, як Цивільний кодекс України, Податковий кодекс України, Бюджетний кодекс України.

3. Частковий характер нормативно-правової бази в сфері розвитку інноваційної діяльності в ОТГ, відсутність консолідуючого нормативноправового акта.

Враховуючи вищезазначене, роль ОТГ як суб’єктів інноваційної діяльності потребує 3 одного боку чіткого обгрунтованого визначення інноваційних пріоритетів у виробничій, соціальній сферах, розвитку інфраструктури життєдіяльності тощо (узгоджених із цілями та завданнями стратегії розвитку регіону), а 3 іншого - оцінки власних і потенційно можливих джерел забезпечення реалізації цих пріоритетів. Вибір моделі взаємодії бізнес-структур та органів влади на регіональному рівні, обгрунтування інноваційних механізмів реалізації інноваційних пріоритетів стратегій розвитку ОТГ має сприяти вирішенню низки завдань: здійснення моніторингу інноваційно-інвестиційного розвитку ОТГ; визначення інноваційного потенціалу ОТГ; оцінювання програмного забезпечення інноваційного та науково-технічного розвитку ОТГ; розроблення організаційно-економічних засад забезпечення конкурентоспроможності ОТГ; формування адекватного завданням стратегії фінансово-економічного механізму забезпечення інноваційного розвитку ОТГ; здійснення стратегічного планування i прогнозування розвитку ОТГ, окремих сфер та галузей господарства ОТГ. Впровадження інноваційних механізмів взаємодії бізнесу та ОТГ дасть змогу активізувати процеси кластеризації економіки регіонів, формування мережевих систем, нових територіально-виробничих форм господарства; забезпечити подальший розвиток інноваційної інфраструктури; визначити оптимальні управлінські моделі інноваційного розвитку з урахуванням системи місцевих факторів впливу [11].

Тому 3 метою вирішення вищезазначених завдань нами визначено шляхи вдосконалення нормативно-правового забезпечення інноваційної інфраструктури ОТГ:

1. Необхідність прийняття базового закону про інноваційну діяльність, 
який регулює цілі і завдання ОТГ в галузі інновацій, що дає базові поняття та визначення, закріплює повноваження органів державної влади різних рівнів, визначає механізм взаємодії між владними органами та суб'єктами інноваційного процесу та ін.

2. Гармонізація між ключовими нормативно-правовими актами, що регулюють інноваційну сферу за напрямками: розвиток малого інноваційного підприємництва, інноваційна інфраструктура, податкове стимулювання інновацій, державні заходи підтримки розвитку суб'єктів інноваційного процесу та ін.

3. Податкове стимулювання розвитку інноваційної діяльності в ОТГ на основі законодавчого введення «податкових парасольок» для суб'єктів різних форм власності, що займаються розробкою і впровадженням принципово нових продуктів (товарів, робіт, послуг) з податку на прибуток, додану вартість, а також на майно юридичних осіб.

4. Розробка єдиних кластерів, баз даних i сховищ 3 формування нормативно-правового забезпечення, яке прямо або опосередковано регулює інноваційну діяльність ОТГ.

5. Удосконалення договірних форм інноваційної діяльності в рамках цивільного права, орієнтованих на необхідність розмежування прав на результати інтелектуальної діяльності і особливості комерціалізації.

6. Розробка нормативного забезпечення в частині технічного регламенту, сертифікації, стандартизації, оцінки відповідності у сфері інновацій і т. д.

Висновки. Таким чином, основою модернізації ОТГ в сучасних умовах $\epsilon$ цілеспрямоване i поступальне вдосконалення законодавчої бази в інноваційній сфері. Чітка регламентація законодавства у сфері інновацій дозволить:

- підвищити рівень інноваційного клімату ОТГ за рахунок зростання обсягів інновацій у всіх галузях науки і промисловості;

- розробити ефективні нормативно закріплені методики аналізу, оцінки та відбору інноваційних проектів;

- знизити конфлікт стейкхолдерів при розробці інноваційної продукції;

- підвищити рівень охорони об'єктів інтелектуальної власності;

- забезпечити зовнішню конкурентоспроможність ОТГ та країни в цілому, запобігти загрози національній безпеці;

- забезпечити єдність судової практики 3 питань регулювання інноваційної діяльності в країні;

- стимулювати розвиток інноваційної діяльності на місцевому, регіональному та державному рівнях;

- забезпечити відповідність і гармонізацію вітчизняних нормативноправових актів у сфері інновацій світовим правовим стандартам і т. д.

Проведене дослідження дозволяє зробити висновок про необхідність подальшого вдосконалення нормативно-правового забезпечення в рамках інноваційного права. Не викликає сумніву, що прийняття єдиного, основного законодавчого акту, а також систематизація чинного законодавства у сфері 
інновацій дозволить забезпечити розвиток науки і техніки в ОТГ та країні в цілому.

Удосконалення законодавства в сфері інновацій та наявність механізму реалізації державної науково-технічної політики спрямовані на забезпечення умов розвитку життєвого циклу інновацій та їх комерціалізацію. Структура нормативно-правового забезпечення розвитку інноваційної інфраструктури ОТГ орієнтована на діючі основи державного регулювання науково-технічної діяльності в Україні.

Варто відзначити, що головна мета щодо вдосконалення законодавства у сфері інновацій орієнтована не тільки на прийняття спеціального нормативно-правового акта, а й внесення змін до галузевих законів, що обумовлено складною природою самих інновацій, обумовлюють комплекс правовідносин, в яких беруть участь різні суб'єкти інноваційного процесу.

Перспективами подальших розвідок $є$ здійснення аналізу основних нормативно-правових механізмів забезпечення розвитку інноваційної інфраструктури зарубіжних країн.

\section{Лimepamypa:}

1. Дацко O.I., Гурняк I.Л., Яремчук O.I. Додана вартість як базис економічного розвитку територіальних громад. Регіональна економіка. 2015. №1. С. 28-37.

2. Кравців В.С., Жук П.В. Концептуальні засади реформування адміністративнотериторіального устрою та місцевого самоврядування в Україні. Регіональна економіка. 2010. № 4. C. 7-16.

3. Деділова Т.В., Шершенюк О.М. Обгрунтування доцільності стратегічної спрямованості держави на інноваційний вектор розвитку. Проблеми $i$ перспективи розвитку підприємнищтва. 2015. № 3(2). С. 9-16.

4. Котов Д.В. Проблема управления инновационным развитием экономики: государство, регион, кластер. Нефтегазовое дело. 2010. № 1. URL: http://ogbus.ru/article/problema-upravleniyainnovacionnym-razvitiemekonomiki-gosudarstvo-region-klaster/

5. Панухник О. Місце сучасних розумних технологій у формуванні інноваційного розвитку об'єднаних територіальних громад України. Прикладна економіка - від теорії до практики: матеріали Міжнародної науково-практичної конференції. Тернопіль: ФОП Осадца Ю. В., 2017. 284 с.

6. Козоріз М.А., Жихор О.Б. Формування і розвиток інноваційної інфраструктури України: окреслення проблем і шляхів їх подолання. Економіка промисловості. 2009. № 3. С. 111-115.

7. Жовнірчик Я.Ф., Мельник В.М. Зарубіжний досвід і вітчизняні традиції здійснення інноваційного розвитку територіальних громад органами місцевого самоврядування. Інвестииії: практика та досвід. 2015. № 9. С. 92-97.

8. Мокій А.І., Павліха Н.В., Науменко Н.С., Дацко О. І. Інституціональне забезпечення інноваційного розвитку територіальних громад України. Регіональна економіка. 2018. №4. С. 17-27.

9. Концепція реформування місцевого самоврядування та територіальної організації влади в Україні:. Постанова КМУ від 01.04.2014 p. №333-p. URL: https://zakon.rada.gov.ua/laws/show/333-2014-\%D1\%80\#Text

10. Про добровільне об'єднання територіальних громад: Закон України від 05.02.2015 p. №157-VIII. URL: https://zakon.rada.gov.ua/laws/show/157-19\#Text

11. Інституційна спроможність об’єднаних територіальних громад України: 
аналітичні записки. URL: https://decentralization.gov.ua/uploads/library/file/475/new_IS.pdf

12. Про інноваційну діяльність: Закон України від 04.07.2002 № 40-IV. URL: http://zakon5.rada.gov.ua/laws/show/40-15 2

13. Про пріоритетні напрями інноваційної діяльності в Україні: Закон України від 08.08.2011 № 3715-VI. URL: http://zakon5.rada.gov.ua/laws/show/3715-17

14. Про наукову і науково-технічну діяльність: Закон України від 18.04.2021 №848VIII. URL: https://zakon.rada.gov.ua/laws/show/848-19\#Text1)

15. Про спеціальний режим інноваційної діяльності технологічних парків : Закон України від 16.07.1999 р. № 991-XIV. URL: http://zakon3.rada.gov.ua/laws/show/991-14

16. Про засади державної регіональної політики: Закон України від 05.02.2015 №156VIII. URL: https://zakon.rada.gov.ua/laws/show/156-19\#Text

17. Про невідкладні заходи щодо забезпечення економічного зростання, стимулювання розвитку регіонів та запобігання корупції: Указ Президента України від 20.09.2019 p. № 713. URL: https://www.president.gov.ua/documents/7132019-29789

18. Про схвалення Стратегії розвитку сфери інноваційної діяльності на період до 2030 року: Розпорядження Кабінет Міністрів України від 10.07.2019 р. № 526-p. URL: https://zakon.rada.gov.ua/laws/show/526-2019-\%D1\%80\#Text

\section{References:}

1. Daczko O.I., Gurnyak I.L., Yaremchuk O.I. (2015). Dodana vartist yak bazy`s ekonomichnogo rozvy`tku tery`torial`ny`x gromad [Added value as a basis for economic development of territorial communities]. Regional na ekonomika - Regional economy, 1, 28-37 [in Ukrainian].

2. Kravciv V.S., Zhuk P.V. (2010) Konceptual’ni zasady` reformuvannya administraty`vno-tery`torial’nogo ustroyu ta miscevogo samovryaduvannya $\mathrm{V}$ Ukrayini [Conceptual principles of reforming the administrative-territorial system and local selfgovernment in Ukraine]. Regional na ekonomika - Regional economy, 4, 7-16 [in Ukrainian].

3. Dedilova T.V., Shershenyuk O.M. (2015). Obg`runtuvannya docil`nosti strategichnoyi spryamovanosti derzhavy` na innovacijny $j$ vektor rozvy`tku [Substantiation of expediency of the strategic orientation of the state on the innovative vector of development]. Problemy $i$ perspekty`vy` rozvy`tku pidpry`yemny`cztva - Problems and prospects of entrepreneurship development, 3(2), 9-16 [in Ukrainian].

4. Kotov D.V. (2010) Problema upravleniya innovacionnym razvitiem ekonomiki: gosudarstvo, region, klaster [The problem of managing the innovative development of the economy: state, region, cluster]. Neftegazovoe delo - Oil and gas business, 1. Retrieved from http://ogbus.ru/article/problema-upravleniya-innovacionnym-razvitiemekonomiki-gosudarstvoregion-klaster/ [in Russian].

5. Panuxny`k O. (2017) Misce suchasny`x rozumny`x texnologij u formuvanni innovacijnogo rozvy`tku ob'yednany`x tery`torial`ny`x gromad Ukrayiny [The place of modern intelligent technologies in the formation of innovative development of united territorial communities of Ukraine]. Pry`kladna ekonomika - vid teoriyi do prakty 'ky`: materialy` Mizhnarodnoyi naukovo-prakty`chnoyi konferenciyi. Ternopil`: FOP Osadcza Yu. V, 284. [in Ukrainian].

6. Kozoriz M.A., Zhy`xor O.B. (2009). Formuvannya i rozvy`tok innovacijnoyi infrastruktury` Ukrayiny`: okreslennya problem i shlyaxiv yix podolannya [Formation and development of innovation infrastructure of Ukraine: outlining problems and ways to overcome them]. Ekonomika promy`slovosti - Industrial economics, 3, 111-115 [in Ukrainian].

7. Zhovnirchy`k Ya.F., Mel`ny`k V.M. (2015). Zarubizhny`j dosvid i vitchy`znyani trady`ciyi zdijsnennya innovacijnogo rozvy`tku tery`torial`ny`x gromad organamy` miscevogo samovryaduvannya [Foreign experience and domestic traditions of innovative development of territorial communities by local governments]. Investy ciyi: prakty 'ka ta dosvid-Investments: practice and experience, 9, 92-97 [in Ukrainian]. 
8. Mokij A.I. , Pavlixa N.V., Naumenko N.S., Daczko O. I. (2018) Insty’tucional’ne zabezpechennya innovacijnogo rozvy`tku tery`torial`ny`x gromad Ukrayiny [Institutional support of innovative development of territorial communities of Ukraine]. Regional na ekonomika - Regional economy, 4, 17-27 [in Ukrainian].

9. Postanova Kabinetu Ministriv Ukrainy "Pro skhvalennia Koncepciyi reformuvannya miscevogo samovryaduvannya ta tery ‘torial 'noyi organizaciyi vlady` v Ukrayini”: vid 01.04.2014 r. \#333-r. [Order of the Cabinet of Ministers of Ukraine "On approval of the Concept of reforming local self-government and territorial organization of power in Ukraine" from 01.04.2014, \#333-r.] zakon.rada.gov.ua. Retrieved from https://zakon.rada.gov.ua/laws/show/333-2014-\%D1\%80\#Text [in Ukrainian].

10. Zakon Ukrayiny "Pro dobrovil'ne ob'yednannya tery`torial’ny`x gromad" : vid 05.02.2015 r. №57-VIII [Law of Ukraine "On voluntary association of territorial communities" from 05.02.2015, № 157-VIII]. zakon.rada.gov.ua. Retrieved from https://zakon.rada.gov.ua/laws/show/157-19\#Text [in Ukrainian].

11. Insty 'tucijna spromozhnist` ob'yednany`x tery`torial`ny`x gromad Ukrayiny`: anality`chni zapy sky` [Institutional capacity of the united territorial communities of Ukraine: analytical notes] (n.d.). Retrieved from: https://decentralization.gov.ua/uploads/library/file/475/new_IS.pdf [in Ukrainian].

12. Zakon Ukrayiny "Pro innovacijnu diyal'nist"” : vid 04.07.2002 № 40-IV. [Law of Ukraine "On innovative activity" from 04.07.2002, № 40-IV.] zakon.rada.gov.ua. Retrieved from http://zakon5.rada.gov.ua/laws/show/40-15 2 [in Ukrainian].

13. Zakon Ukrayiny "Pro priory`tetni napryamy` innovacijnoyi diyal’nosti v Ukrayini" : vid 08.08.2011 № 3715-VI [Law of Ukraine “On priority areas of innovation in Ukraine" from 08.08.2011, № 3715-VI]. zakon.rada.gov.ua. Retrieved from: http://zakon5.rada.gov.ua/laws/show/3715-17 [in Ukrainian].

14. Zakonu Ukrayiny "Pro naukovu i naukovo-texnichnu diyal'nist": vid 18.04.2021 №848-VIII. [Law of Ukraine "On scientific and scientific-technical activity" from 18.04.2021, № 848-VIII]. zakon.rada.gov.ua. Retrieved from https://zakon.rada.gov.ua/laws/show/84819\#Text [in Ukrainian].

15. Zakon Ukrayiny "Pro special`ny’j rezhy’m innovacijnoyi diyal’nosti texnologichny’x parkiv" : vid 16.07.1999, № 991-XIV [Law of Ukraine "On the special regime of innovative activity of technology parks”, from 16.07.1999, № 991-XIV.]. zakon.rada.gov.ua. Retrieved from http://zakon3.rada.gov.ua/laws/show/991-14 [in Ukrainian].

16. Zakon Ukrayiny "Pro zasady` derzhavnoyi regional’noyi polity'ky" : vid 05.02.2015 №156-VIII. [Law of Ukraine "On the principles of state regional policy" from 05.02.2015 №156-VIII] zakon.rada.gov.ua. Retrieved from https://zakon.rada.gov.ua/laws/show/15619\#Text [in Ukrainian].

17. Ukaz Prezy'denta Ukrayiny "Pro nevidkladni zaxody" shhodo zabezpechennya ekonomichnogo zrostannya, sty'mulyuvannya rozvy'tku regioniv ta zapobigannya korupciyi": vid 20.09.2019, № 713. [Decree of the President of Ukraine "On urgent measures to ensure economic growth, stimulate regional development and prevent corruption” from 20.09.2019, № 713]. zakon.rada.gov.ua. Retrieved from https://www.president.gov.ua/documents/713201929789 [in Ukrainian].

18. Rozporyadzhennya Kabinet Ministriv Ukrayiny "Pro sxvalennya Strategiyi rozvy`tku sfery` innovacijnoyi diyal ’nosti na period do 2030 roku”: vid 10.07.2019 r., № 526-r. [Order of the Cabinet of Ministers of Ukraine "On approval of the Strategy for the development of innovation for the period up to 2030" from 10.07.2019, № 526-r.] zakon.rada.gov.ua. Retrieved from https://zakon.rada.gov.ua/laws/show/526-2019-\%D1\%80\#Text [in Ukrainian]. 